\title{
AC 2009-667: ADDING CIVIL ENGINEERING TO A DEPARTMENT THAT CURRENTLY IS HOME TO CIVIL ENGINEERING TECHNOLOGY
}

Scott Wolcott, Rochester Institute of Technology

Todd Dunn, Rochester Institute of Technology 


\section{Adding Civil Engineering Curricula to an Existing Civil Engineering Technology Department}

\section{Introduction}

The purpose of this Civil Engineering Program Exploration Report is to investigate the feasibility, benefits, and potential costs of administrating an ABET-EAC accredited civil engineering (CE) program within a single administrative unit at our University. Our department would be "home" for both civil engineering (ABET-EAC) and civil engineering technology (ABET-TAC) programs.

It should be noted that the idea of starting a civil engineering program at our University is not new. In 1996, the Civil Engineering Technology (CET) chair had conversations with members of the Engineering College at our University. The Engineering College is a separate administrative unit from the college in which the existing CET program is now housed. In 2001, two professors from the CET department approached administrators in the Engineering College with a proposal to administer a new CE program in the mechanical engineering (ME) department, but teach essential civil engineering courses from the existing Civil Engineering Technology offerings. The administrators of the mechanical department and the Engineering College did not pursue the proposal. It's possible that such an arrangement would have created more problems than it solved and could have had a negative impact on the existing CET program.

The reason for starting a CE program at our University has never been to increase student enrollment. The motivation is simple and centered around how best to serve our primary constituents - the students. A CE program would provide a track for interested and capable CET students to pursue an ABET-EAC BS degree in civil engineering at our University. There are seemingly straightforward and compelling advantages of a CE program - elimination of temporal and spatial licensure issues, easier graduate school acceptance (sometimes a bias issue), and avoiding professional prejudice. However, this document will report that some of these advantages are not as clear today as in the past. In fact, the graduate school and licensure opportunities for holders of BS degrees in CE or CET may be nearly identical in the future.

\section{Proposed Curriculum}

A proposed CE course list (Figure 1) and block schedule have been developed based on ABETEAC criteria for 2008-2009 Accreditation Cycle ${ }^{21}$, conversations with ABET-EAC/TAC evaluators, and review of curricula at selected peer institutions. The existing CET check list is presented in Figure 2 for comparison. Courses that have been dropped from the existing CET curriculum are shaded. Please note that our University is on a quarterly schedule. 


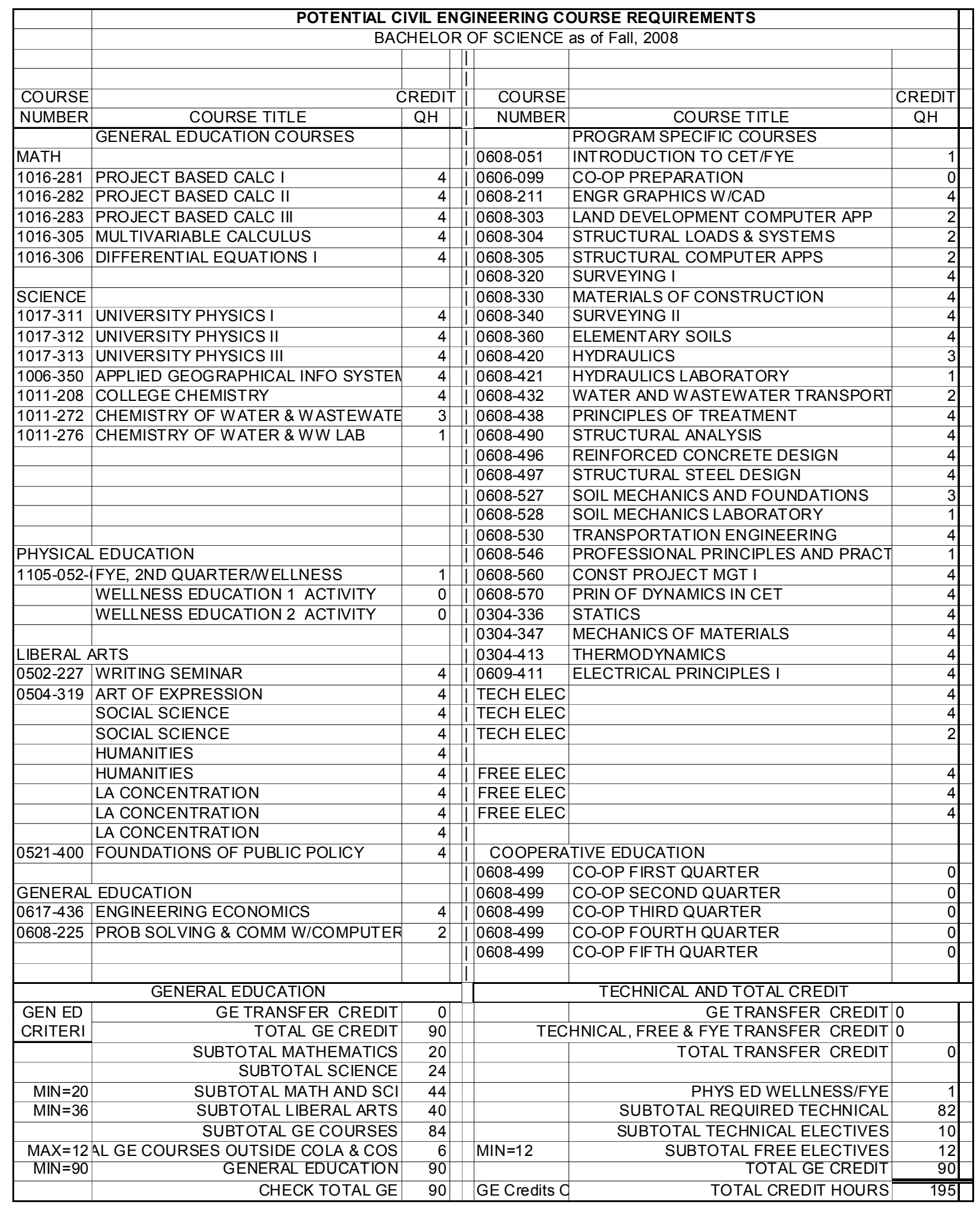

Figure 1: Proposed CE Check List 


\begin{tabular}{|c|c|c|c|c|c|}
\hline & \multirow{2}{*}{\multicolumn{5}{|c|}{$\begin{array}{c}\text { CIVIL ENGINEERING TECHNOLOGY COURSE REQUIREMENTS } \\
\text { BACHELOR OF SCIENCE as of Fall, } 2008\end{array}$}} \\
\hline & & & & & \\
\hline & & & & & \\
\hline & & & & & \\
\hline COURSE & & REDIT & COURSE & & CREDIT \\
\hline NUMBER & COURSE TITLE & $\mathrm{QH}$ & NUMBER & COURSE TITLE & $\mathrm{QH}$ \\
\hline & GENERAL EDUCATION COURSES & & & PROGRAM SPECIFIC COURSES & \\
\hline MATH & & & 0608-051 & INTRODUCTION TO CET/FYE & 1 \\
\hline $1016-X X X$ & MATH ELECTIVE & 4 & 0606-099 & CO-OP PREPARATION & 0 \\
\hline $1016-230$ & PRE CALC & 4 & 0608-211 & ENGR GRAPHICS W/CAD & 4 \\
\hline 1016-231 & CALC FOR TECH I & 4 & $0608-220$ & CIVIL ENGINEERING GRAPHICS & 4 \\
\hline 1016-232 & CALC FOR TECH II & 4 & 0608-303 & |LAND DEVELOPMENT COMPUTER APP & 2 \\
\hline 1016-304 & DIFF EQTNS FOR ET & 4 & 0608-304 & STRUCTURAL LOADS \& SYSTEMS & 2 \\
\hline & & & 0608-305 & STRUCTURAL COMPUTER APPS & 2 \\
\hline SCIENCE & & & $0608-320$ & SURVEYING I & 4 \\
\hline $1017-211$ & COLLEGE PHYSICS I & 4 & 0608-330 & MATERIALS OF CONSTRUCTION & 4 \\
\hline $1017-212$ & COLLEGE PHYSICS ॥ & 4 & $0608-340$ & SURVEYING ॥ & 4 \\
\hline $1017-213$ & COLLEGE PHYSICS III & 4 & $0608-360$ & ELEMENTARY SOILS & 4 \\
\hline 1017-359 & ELECTRONICS TECHNOLOGY & 4 & 0608-380 & ELEMENTARY STRUCTURES & 4 \\
\hline $1011-271$ & FUNDAMENTALS OF CHEMISTRY & 3 & 0608-404 & APPLIED MECHANICS OF MATERIALS & 4 \\
\hline 1011-205 & CHEMISTRY I LAB & 1 & $0608-420$ & HYDRAULICS & 3 \\
\hline $1011-272$ & CHEMISTRY OF WATER \& WASTEWATER & 3 & $0608-421$ & HYDRAULICS LABORATORY & 1 \\
\hline $1011-276$ & CHEMISTRY OF WATER \& WW LAB & 1 & $0608-422$ & ELEMENTS OF BUILDING CONSTRUCTION & 4 \\
\hline & & & 0608-432 & WATER AND WASTEW ATER TRANSPORT & 2 \\
\hline & & & $0608-438$ & PRINCIPLES OF TREATMENT & 4 \\
\hline & & & $0608-490$ & STRUCTURAL ANALYSIS & 4 \\
\hline & & & $0608-496 / 7$ & STRUCTURAL DESIGN & 4 \\
\hline PHYSICAL & LEDUCATION & & $0608-527$ & SOIL MECHANICS AND FOUNDATIONS & 3 \\
\hline $1105-052-1$ & FYE, 2ND QUARTERMELLNESS & 1 & $0608-528$ & SOIL MECHANICS LABORATORY & 1 \\
\hline & WELLNESS EDUCATION 1 ACTIVITY & 0 & $0608-530$ & TRANSPORTATION ENGINEERING & 4 \\
\hline & WELLNESS EDUCATION 2 ACTIVITY & 0 & 0608-546 & PROFESSIONAL PRINCIPLES AND PRACTIC & 1 \\
\hline & & & $0608-570$ & PRIN OF DYNAMICS IN CET & 4 \\
\hline LIBERAL $A$ & ARTS & & 0610-302 & INTRODUCTION TO STATICS & 4 \\
\hline $0502-227$ & WRITING SEMINAR & 4 & $0610-303$ & STRENGTH OF MATERIALS & 4 \\
\hline $0504-319$ & ART OF EXPRESSION & 4 & TECH ELEC & & 4 \\
\hline & SOCIAL SCIENCE & 4 & TECH ELEC & & 4 \\
\hline & SOCIAL SCIENCE & 4 & TECH ELEC & & 2 \\
\hline & HUMANITIES & 4 & & & \\
\hline & HUMANITIES & 4 & FREE ELEC & & 4 \\
\hline & LA CONCENTRATION & 4 & FREE ELEC & & 4 \\
\hline & LA CONCENTRATION & 4 & FREE ELEC & & 4 \\
\hline & LA CONCENTRATION & 4 & & & \\
\hline $0535-403$ & EFFECTIVE TECHNICAL COMMUNICATION & 4 & COOPERA & TTIVE EDUCATION & \\
\hline & & & $0608-499$ & CO-OP FIRST QUARTER & 0 \\
\hline GENERAL & - EDUCATION & & 0608-499 & CO-OP SECOND QUARTER & 0 \\
\hline $0617-436$ & ENGINEERING ECONOMICS & 4 & $0608-499$ & CO-OP THIRD QUARTER & 0 \\
\hline $0608-225$ & PROB SOLVING \& COMM W/COMPUTERS & 2 & 0608-499 & CO-OP FOURTH QUARTER & 0 \\
\hline & & & 0608-499 & CO-OP FIFTH QUARTER & 0 \\
\hline & & & & & \\
\hline & GENERAL EDUCATION & & & TECHNICAL AND TOTAL CREDIT & \\
\hline GEN ED & GE TRANSFER CREDIT & 0 & & \begin{tabular}{|c|} 
GE TRANSFER CREDIT \\
\end{tabular} & 0 \\
\hline CRITERI & TOTAL GE CREDIT & 90 & & ECHNICAL, FREE \& FYE TRANSFER CREDIT & 0 \\
\hline & SUBTOTAL MATHEMATICS & 20 & & \begin{tabular}{|c|} 
TOTAL TRANSFER CREDIT \\
\end{tabular} & 0 \\
\hline & SUBTOTAL SCIENCE & 24 & & & \\
\hline $\mathrm{MIN}=20$ & SUBTOTAL MATH AND SCl & 44 & & PHYS ED WELLNESS/FYE & 1 \\
\hline $\mathrm{MIN}=36$ & SUBTOTAL LIBERAL ARTS & 40 & & SUBTOTAL REQUIRED TECHNICAL & 82 \\
\hline & SUBTOTAL GE COURSES & 84 & & SUBTOTAL TECHNICAL ELECTIVES & 10 \\
\hline $\mathrm{MAX}=12$ & BTOTAL GE COURSES OUTSIDE COLA \& COS & 6 & $\mathrm{MIN}=12$ & SUBTOTAL FREE ELECTIVES & 12 \\
\hline $\mathrm{MIN}=90$ & GENERAL EDUCATION & 90 & & TOTAL GE CREDIT & 90 \\
\hline & CHECK TOTAL GE & 90 & & TOTAL CREDIT HOURS & $\overline{195}$ \\
\hline
\end{tabular}

Figure 2: Existing CET Check List (Shaded areas indicate modifications) 
The ABET-EAC Program Criteria addressing curriculum and faculty are as follows:

\section{a. Curriculum}

"The program must demonstrate that graduates can: apply knowledge of mathematics through differential equations, calculus-based physics, chemistry, and at least one additional area of science, consistent with the program objectives; apply knowledge of four technical areas appropriate to civil engineering; conduct civil engineering experiments and analyze and interpret the resulting data; design a system, component, or process in more than one civil engineering context; explain basic concepts in management, business, public policy, and leadership; and, explain the importance of professional licensure."

\section{b. Faculty}

"The program must demonstrate that faculty teaching courses that are primarily design in content are qualified to teach the subject matter by virtue of professional licensure, or by education and design experience. The program must demonstrate that it is not critically dependent on one individual".

The ABET-EAC program-specific criteria) resulted in the following courses being added to the existing base CET curriculum:

- Math sequence changed from ET to engineering. Other acceptable math sequences exist for engineering programs. However, for brevity, only one has been presented in this paper.

○ Project based calculus I, II, and III

○ Multivariable Calculus

○ Differential Equations I

- The physics sequenced changed from algebra based to calculus based physics

○ University Physics I, II, and III

- Switched the "Effective Technical Communications" course to "Foundations of Public Policy" course. "Effective Technical Communications" is a good course, but "Foundations of Public Policy" satisfies one of the ABET-EAC criteria.

- Changed "Construction Project Management I" from a technical elective to a required course.

- "College Chemistry" replaces "Fundamental of Chemistry."

\section{ABET Accreditation Issues}

Two accreditation issues were investigated: 1) Can an ABET-EAC program be administered outside the Engineering College at our University and 2) Can existing CET courses be used in the CE curriculum? The answer to both these questions is... probably yes.

The commissioner for the ABET Technology Accreditation Commission ${ }^{22}$, the past Chair of TAC of $\mathrm{ABET}^{23}$ (and current Chair of IEEE Accreditation Policy Council; the council addresses issues in $\mathrm{EAB}, \mathrm{TAC}$, and $\mathrm{CAC}$ accreditation), and an experienced ABET evaluator ${ }^{24}$ at our University all concurred that ABET does not care where programs are administered. This is important for several reasons, not the least of which is avoiding the possibility of creating a 
program in a different college that would compete with our existing CET program, which is not housed in the Engineering College. Yes, the CE program, if created within our department, would probably draw from the CET student population. However, there would be little to no internal strife between departments or colleges. Both programs could co-exist in our department. There are six institutions that have both civil engineering and civil engineering technology or some closely related design-based program. These institutions include:

- Florida A\&M ${ }^{9,10}$

- Old Dominion University ${ }^{11,12}$

- University of Massachusetts Lowell ${ }^{13,14}$

- University of North Carolina Charlotte ${ }^{15,16}$

- University of Toledo ${ }^{17,18}$

- Youngstown State University ${ }^{19,20}$

While none of these schools have both programs administered from the same department, most are in the same college. These colleges contain both engineering departments and engineering technology departments. Anecdotal evidence suggests that the relationships between CE and CET programs at some of these institutions are not collegial. Some have suggested that CET programs have suffered if they are perceived to be doing a better "job" than CE programs. The CET program at our University currently enjoys good relationships with other programs across campus and is happily not involved in significant turf battles.

The answer to the second question, "Can existing civil engineering technology courses be used in the CE curriculum?" also seems to be affirmative. This author had a long telephone conversation with a past Chair of TAC of $\mathrm{ABET}^{22}$ who has significant experience as an American Society of Civil Engineers (ASCE), and represented ASCE on TAC for five years. This individual felt that using existing CET courses to obtain ABET-EAC is "doable." Accreditation is an outcome-based assessment. The individual also did not feel that bias of individual evaluators would be a problem.

This author also spoke with a faculty member from a university in the Midwest ${ }^{25}$. A few years ago this university discontinued its CET program and started an ABET-EAC Civil Engineering program. This faculty member was the principle author of this effort. He reported that very little content changed in core civil engineering courses like structural analysis and hydraulics. 
Therefore, most civil engineering core courses would be co-listed with CE and CET. Required $\mathrm{CE}$ courses that currently exist in CET include:

- Engineering Graphics with ACAD

- Land Development Computer Applications

- Structural Loads \& Systems

- Surveying I \& II

- Materials of Construction

- Elementary Soils

- Hydraulics

- Water and Wastewater Transport
- Principles of Water and WW Treatment

- Structural Analysis

- Reinforced Concrete Design

- Structural Steel Design

- Soil Mechanics and Foundations

- Transportation Engineering

- Professional Principles and Practice

- Construction Project Management I

- Principles of Dynamics in CET

Courses from the Engineering College would be preferable for an ABET-EAC degree in some cases. Therefore, "Statics" and "Mechanics of Materials" replaces "Introduction to Statics," "Strength of Materials," and "Applied Mechanics."

\section{Review of Peer Institutions}

Peer institutions were selected based on several criteria including: perceived quality; quarterly academic quarters; recent CET to CE curricular changes; and cooperative education. Detailed curricula from these institutions is available upon request as an excel spreadsheet. Selected peer institutions include the following:

- Ohio State University ${ }^{3}$

- Rose Hulman Institute of Technology ${ }^{4}$

- Stanford University - Structural and Construction (DRY) $\operatorname{Track}^{5}$

- Stanford University - Environmental and Water Resources (WET) Track ${ }^{5}$

- University of Cincinnati ${ }^{6}$

- Drexel University ${ }^{7}$

- Oregon Institute of Technology 8

The current CET curriculum is very similar to the curricula of the peer institutions. In comparison, the CET program has similar and a good overall balance in required courses between the 4 design fields - structural, geotechnical, transportation and environmental. Some programs had one or more required courses in project/construction management. A required Geospatial Information Systems (GIS) course also occurred in several CE curricula. Many of the peer curricula also included "FE review" courses like thermodynamics and electrical principles. The CET program at our university requires an electrical principles general education course and allows thermodynamics to be taken as a technical elective. However, very few students have taken thermodynamics. 
Based on the review of CE programs, the following courses were added:

- Applied Geographical Information Systems (General Education course)

- Construction Project Management I

- Thermodynamics

- Electrical Principles I

NOTE: New ABET-EAC program criteria have been adopted by the ABET Board of Directors as of 11/3/2007 for the 2008-2009 accreditation cycle ${ }^{21}$. Therefore, it is anticipated that many, if not all, of the existing ABET-EAC curricula may be slightly modified to account for changes to the accreditation criteria

\section{Enrollment}

Enrollment data has been limited to what data this author could collect. Table 1 compares 2007 graduation rates (Spring 2008) of CET and CE programs. On average, the institutions with CET and CE programs had fewer graduates than institutions with either CET or CE programs. However, the average combined graduation numbers were higher for institutions with both CET and CE programs. Table 1 also presents some interesting numbers concerning female graduates in CE and CET. Detailed results for programs at specific universities are shown in Table 2.

Table 1 Graduation Numbers from Spring $2008^{26}$

\begin{tabular}{|l|c|c|}
\hline & $\begin{array}{c}\text { Average } \\
\text { Number of } \\
\text { Total } \\
\text { Graduates }\end{array}$ & $\begin{array}{c}\text { Average \% } \\
\text { of Female, } \\
\text { Graduates }\end{array}$ \\
\hline CET at our University & 49 & 20 \\
\hline Total program average & 31 & 22 \\
\hline CE average of ALL Institutions & 35 & 23 \\
\hline CET average of ALL Institutions & 25 & 21 \\
\hline CE Average of Institutions w/CE \& CET & 26 & 21 \\
\hline CET Average of Institutions w/CE \& CET & 20 & 24 \\
\hline CE Average of Institutions w/o CET & 39 & 24 \\
\hline CET Average of Institutions w/o CE & 30 & 19 \\
\hline
\end{tabular}

Table 2 presents 2007 graduation rates (Spring 2008) from regional and national CE and CET programs. The current CET enrollment at our university is strong. Last year's graduation class was $4^{\text {th }}$ largest of the CE and CET surveyed. Our CET graduation class was larger than two potential CE competitors in our state.

The Fall 2008 freshmen class in CET was a record. Forty seven students were registered for the "First Year Experience" course. (2008). 
Table 2 Number of Graduates from CE and CET programs, $2007^{26}$.

\begin{tabular}{|c|c|c|c|c|}
\hline University & $\underline{\text { Program }}$ & $\frac{\text { Total }}{\text { Graduates }}$ & $\frac{\text { Female }}{\text { Graduates }}$ & $\begin{array}{l}\text { \% Female } \\
\text { Graduates }\end{array}$ \\
\hline Clarkson University & $\mathrm{CE}$ & 67 & 6 & $9.0 \%$ \\
\hline Ohio State University & $\mathrm{CE}$ & 61 & 10 & $16.4 \%$ \\
\hline Wentworth Institute of Technology & CET & 50 & 10 & $20.0 \%$ \\
\hline Rochester Institute of Technology & CET & 49 & 10 & $20.4 \%$ \\
\hline University of Cincinnati & $\mathrm{CE}$ & 47 & 5 & $10.6 \%$ \\
\hline Univ. of N.Carolina@ Charlotte & $\mathrm{CE}$ & 45 & unknown & \\
\hline Syracuse University & $\mathrm{CE}$ & 45 & unknown & \\
\hline Rose Hulman Institute of Tech. & $\mathrm{CE}$ & 41 & 10 & $24.4 \%$ \\
\hline Florida A \& M University & $\mathrm{CE}$ & 40 & 10 & $25.0 \%$ \\
\hline Old Dominion University & $\mathrm{CE}$ & 38 & unknown & \\
\hline Stanford Univ.(Structural Track) & $\mathrm{CE}$ & 37 & 15 & $40.5 \%$ \\
\hline SUNY University at Buffalo & $\mathrm{CE}$ & 36 & 7 & $19.4 \%$ \\
\hline Youngstown State University & CET & 36 & 2 & $5.6 \%$ \\
\hline Southern Polytechnic State Univ. & CET & 32 & 10 & $31.3 \%$ \\
\hline Old Dominion University & CET & 31 & 6 & $19.4 \%$ \\
\hline Oregon Institute of Technology & $\mathrm{CE}$ & 29 & 6 & $20.7 \%$ \\
\hline University of Mass.@Lowell & CET & 20 & 0 & $0.0 \%$ \\
\hline Univ. of N. Carolina@ Charlotte & CET & 18 & 3 & $16.7 \%$ \\
\hline University of Toledo & $\mathrm{CE}$ & 18 & 0 & $0.0 \%$ \\
\hline Temple University & $\mathrm{CE}$ & 16 & 7 & $43.8 \%$ \\
\hline Western Kentucky University & $\mathrm{CE}$ & 15 & 2 & $13.3 \%$ \\
\hline SUNY Institute of Technology & CET & 14 & 3 & $21.4 \%$ \\
\hline Stanford (WREE Track) & $\mathrm{CE}$ & 13 & 8 & $61.5 \%$ \\
\hline Youngstown State University & $\mathrm{CE}$ & 13 & 2 & $15.4 \%$ \\
\hline Temple University & CET & 11 & 0 & $0.0 \%$ \\
\hline Bluefield State College & CET & 7 & 0 & $0.0 \%$ \\
\hline \multirow[t]{3}{*}{ Florida A \& M University } & CET & 1 & 1 & $100.0 \%$ \\
\hline & \multirow{2}{*}{$\begin{array}{l}\text { Average: } \\
\text { Median: }\end{array}$} & 31 & \multirow{2}{*}{$\begin{array}{l}\text { Average: } \\
\text { Median: }\end{array}$} & $22.3 \%$ \\
\hline & & 32 & & $19.4 \%$ \\
\hline
\end{tabular}

Projecting enrollment in a CE program and the new program's impact on enrollment in the existing CET program is difficult to accurately assess. The enrollment projections offered in 
Table 3 are based entirely on the information presented in Table 1, a basic understanding of enrollment growth in start-up programs, and cursory knowledge of the demographics of high school population projections. The size of the 2010 high school graduation class is at or near the peak of the current high school enrollment bubble.

Table 3 presents "best guess" enrollment projections for CE and CET. The estimates assume that the CE program would start sometime in the future when the high school graduate bump has passed. It is assumed that the CE program will start small and grow in five years to a sustainable number of 34 incoming freshman. The 34 incoming freshman is generated by adding $30 \%$ to the average graduation rate for CE programs at institutions with a CET program. The additional students accounts for attrition, assuming a 70\% retention rate. It is likely that there would be a decrease in the number of incoming freshmen to CET. Some of the students who currently enroll as freshmen in CET and have very strong math skills would choose to enroll in $\mathrm{CE}$ instead. However, not all of the "strongest" students would choose CE over CET. Some excellent students who want to concentrate in construction management from year one will remain CET students. Another factor that can be considered is that the CET program will "catch" students who originally enrolled in CE, but have difficulty with the math and science requirements. This could have the effect of "safeguarding" the CE program retention numbers under the current retention counting system employed at our University.

Note that the current CET program graduates more students than enter the program for that cohort. Fifteen to 20 students transfer to the CET program every year. This number may be reduced by choosing to transfer into the $\mathrm{CE}$ program instead and the fact that a neighboring school in our state is reportedly starting a CET program. This neighbor school is one of the CET program "feeder schools".

Table 3 Freshman Enrollment Projections for CE and CET at our University

\begin{tabular}{|l|c|c|c|c|c|}
\hline Program & Year 1 & Year 2 & Year 3 & Year 4 & Year 5 \\
\hline \hline $\begin{array}{l}\text { Civil } \\
\text { Engineering } \\
\text { Technology }\end{array}$ & 39 & 35 & 32 & 28 & 25 \\
\hline $\begin{array}{l}\text { Civil } \\
\text { Engineering }\end{array}$ & 5 & 12 & 20 & 28 & 34 \\
\hline
\end{tabular}

\section{CE and CET Brand Confusion}

Most prospective students and their parents ask what the difference is between CE and CET during campus visits at our University. We explain the difference in terms of calculus requirements, program goals, practical experience of instructors, and licensing issues. People seem to walk away from the experience with their heads spinning, but understanding the differences between ABET-TAC and ABET-EAC programs. There should not be any additional confusion if a $\mathrm{CE}$ program were offered within our department. In fact, it should be reassuring for parents to know that BOTH programs are offered within the same department and that their child could easily transfer between the two.

The question of program identity and the level of confusion that may exist when differentiating each program to prospective students and their parents was not asked of the current institutions 
that have both $\mathrm{CE}$ and CET programs. Many CET programs at the combined institutions closely resemble a construction management program rather than a design orientated CET program at our University. The difference between construction management and CE would be easier to explain.

\section{Employment}

The job market for CET graduates and co-ops was very strong prior to the current economic downturn. Employment rates for fulltime and co-op employment was practically $100 \%$. Our graduates are able to find employment locally, regionally, nationally and in rare cases globally. While most jobs are found in our region, CET job opportunities are expanding geographically. It would be a safe assumption that CE graduates enjoy the same job market as our current CET students.

How might adoption of a CE program impact employment for CET graduates? A survey was performed to attempt to determine if employers of our graduates and co-op students have any preferences in degree title. This very unscientific survey was distributed to approximately 50 employers. Eleven people responded, but only 10 answered the survey questions as posed.

Table 4 Potential Impact of CE graduates on CET employment. ${ }^{31}$

\begin{tabular}{|c|c|c|c|c|}
\hline & Survey Question & Yes & No & $\mathrm{N} / \mathrm{A}$ \\
\hline & $\begin{array}{l}\text { If our university offers a Civil Engineering degree, would your } \\
\text { company likely hire these graduates? }\end{array}$ & 11 & 0 & \\
\hline 2 & $\begin{array}{l}\text { Would you hire the civil engineering graduate rather than a civil } \\
\text { engineering technology graduate? }\end{array}$ & 7 & 3 & \\
\hline 3 & $\begin{array}{l}\text { If our university offers a Environmental Engineering degree, would } \\
\text { your company likely hire these graduates? }\end{array}$ & 8 & 2 & \\
\hline & $\begin{array}{l}\text { Would you hire the environmental engineering graduate rather than a } \\
\text { civil engineering technology graduate? }\end{array}$ & 4 & 6 & \\
\hline 5 & $\begin{array}{l}\text { If our university offers a Construction Management degree would } \\
\text { your company likely hire these graduates? }\end{array}$ & 3 & 4 & 3 \\
\hline 6 & $\begin{array}{l}\text { Would you hire the construction management graduate rather than a } \\
\text { civil engineering technology graduate? }\end{array}$ & 1 & 3 & 6 \\
\hline 7 & $\begin{array}{l}\text { If our university offers any of the above mentioned degrees would } \\
\text { you likely hire fewer Civil Engineering Technology (CET) } \\
\text { graduates? }\end{array}$ & 9 & 1 & \\
\hline 8 & $\begin{array}{l}\text { Which degree would have the greatest effect on the number of Civil } \\
\text { Engineering Technology (CET) graduates you hire? }\end{array}$ & 10 & 0 & 0 \\
\hline
\end{tabular}

Employers answered "Not Applicable" (N/A) on questions 5 and 6 because they do not manage construction projects at their firm. Therefore, they would not hire a construction management graduate.

It would seem, based on this survey, that a program in CE could have a significant negative impact on the employment opportunities for CET graduates. The impact might be minimized if there is a strong job market. However, it seems clear that employers would have a preference for the CE grads over CET grads which could create a "class" structure within the program. 
The most common reason for a preference to hire CE over CET graduates is licensure, not ability. Employment is an area where personal bias also plays a role in hiring. This bias is not limited to CE vs. CET. Some engineering firms will have a preference for graduates from the same institution that the firm's principle(s) attended.

\section{Potential Costs}

The potential CE curriculum presented in Figure 2 consists of $100 \%$ existing courses at our University. Therefore, the cost of teaching (i.e. additional faculty, associated office space and labs) would be very small, if any. Additional teaching costs may occur if enrollment out paces the projected decreases in high school demographics. In this case, additional sections may be required and additional faculty would be hired to teach.

It is not anticipated that the addition of a CE program would increase scholarly costs at our University. At this stage of our university's scholarly evolution, the administration is promoting scholarly expectations of faculty that are independent of the program where faculty teaches. It is assumed that laboratories, personnel, and equipment needed for research will be adequately supported by our College and the University for CET and CE faculty.

\section{Graduate School Opportunities}

This section has been developed based on personal experiences over the past 12 years advising CET graduates. Graduates holding a BS degree in CE have had an historic advantage over CET graduates. Civil engineering graduate coordinators have required that incoming students have engineering calculus sequences and calculus based physics. Other times, graduate coordinators have required CET graduates to retake some courses at an ABET-EAC program. A few institutions have and still do exhibit a strong bias against CET graduates and flatly refuse acceptance. Nevertheless, approximately five to ten percent of our CET graduates are accepted into graduate school each year.

The advantage of CE graduates over CET graduates seems to be decreasing. Last year a solid CET graduate $(\mathrm{GPA} \sim 3.1)$, but not exceptional, was accepted into several civil engineering graduate programs, including Cornell University, the University of New Hampshire (UNH), and SUNY Buffalo. He was offered graduate assistance at the regional university and $\mathrm{UNH}^{32}$

Representatives from SUNY Buffalo asked the CET graduate why there weren't more graduates from our University applying to the program. They had expected connection between the two universities. Unfortunately, in the past, it had been somewhat troublesome for our graduates to gain acceptance to graduate programs at this university. We have had successful candidates, but also some frustration which generated a negative reputation among our graduates. However, the environment seems to be improving at this regional university.

It is possible that future opportunities for CET graduates being admitted into graduate programs will increase. The American Society of Civil Engineers (ASCE) has been promoting graduate school education as a requirement for admittance into the PE exam for several years. The most recent proposal is called Body of Knowledge $(\mathrm{BOK})+30$. $\mathrm{BOK}+30$ will require engineering interns with a bachelor's degree to obtain an additional 30 semester credits of acceptable upperlevel undergraduate or graduate-level coursework from approved course providers. The PE candidates will also need to document a specific record of an additional 4 years or more of progressive experience on engineering projects of a grade and character which indicate to a 
licensing board that the applicant may be competent to practice engineering. The latter is an existing requirement in many states for graduates from ABET-EAC programs.

What does this mean for CET graduates and graduate school? To be honest, no one knows for certain. One possibility is that graduate programs will begin to relax admittance criteria to their ME (Master of Engineering) programs. The Master of Science (MS) programs will be reserved and perhaps remolded specifically as a pathway to a doctorate. The MS and ME typically have nearly identical curricular requirements. The difference is that a thesis is required for an MS and a graduate project is a requirement of an ME. This process is in the latter planning stages in at least one civil engineering graduate program.

\section{PE Licensure}

Graduates from ABET-EAC programs with at least four years of documented design experience are admitted into the PE exam in all 50 states. A candidate holding an MS degree in civil engineering from an institution that has an ABET-EAC program reduces the requirement of documented design experience to three years.

The current environment for CET graduates to obtain their professional engineer (PE) license is much more confusing, at best. The rules for licensure are established by individual states. Table 5 presents the results of a recent survey of state by state academic requirements.

It should be noted that a conversation between the president of our University and a CET alumnus provided the catalyst for the study that led to this paper. The individual complained that a PE license is difficult to obtain in Florida. In fact, a PE license has become easier for a CET graduate to obtain because of a successful lawsuit brought against the licensing board of Florida.

It would be interesting to determine how many CET graduates reside either in states where there are additional academic requirements for licensure (12) or in states that do not recognize ABETTAC degrees (3). The percentage of CET graduates that wish to become licensed should also be considered. For example, construction managers do not need a license. 
Table 5 Academic Requirements for PE Exam Admittance ${ }^{27,28,29,30}$

\begin{tabular}{|l|l|l|l|l|}
\hline States that admit ABET-TAC (CET) graduates w/o additional academic criteria - 31 \\
\hline Alaska & Hawaii & New Hampshire & Oklahoma & Washington \\
\hline Arizona & Idaho & New Jersey & Oregon & Wisconsin \\
\hline California & Maine & New Mexico & Pennsylvania & West Virginia \\
\hline Colorado & Maryland & New York & South Dakota & \\
\hline Connecticut & Massachusetts & North Carolina & Texas & \\
\hline Delaware & Montana & North Dakota & Vermont & \\
\hline Georgia & Nevada & Ohio & Virginia & \\
\hline $\begin{array}{l}\text { States that require ABET-TAC (CET) graduates to submit transcripts and work experience for } \\
\text { review - 4 }\end{array}$ & Indiana & Minnesota & South Carolina \\
\hline Florida & $\begin{array}{l}\text { States that require ABET-TAC (CET) graduates to obtain a CE MS degree from an Institution } \\
\text { that has an ABET-EAC CE undergraduate program - 12 }\end{array}$ \\
\hline Alabama & Iowa & Louisiana & Missouri \\
\hline Arkansas & Kansas & Michigan & Tennessee \\
\hline Illinois & Kentucky & Mississippi \\
\hline States that do not recognize ABET-TAC (CET) graduates - 3 & Rtah \\
\hline Nebraska & Rhode Island \\
\hline
\end{tabular}

The data in Table 5 were collected through an evaluation of NCEES 2007 survey results ${ }^{27}$, interpretation of state license board rules and regulations ${ }^{28}$, phone conversations with state license board representatives ${ }^{29}$, and a very helpful review by ETD list serve members ${ }^{30}$. The results presented in Table 5 are "relatively" accurate. The answers to the author's questions sometimes varied depending upon who answered the phone. The review by the ETD list serve members corrected most errors. Some ETD list serve members suggested that written rules are sometimes not the practice in a two states. This assertion couldn't be confirmed.

The future may be murkier for licensure of CET graduates as well as CE graduates. The NCEES is a national non-profit organization composed of engineering and surveying licensing boards representing all states and U.S. territories. NCEES develops, scores, and administers the examinations used for engineering and surveying licensure throughout the United States.

NCEES makes recommendations to state licensing boards regarding criteria to sit for the FE and the PE exams. State legislatures must approve these recommendations.

In 2006, NCEES by a vote of 39 to 27, adopted ASCE's BOK +30 proposals as a requirement to sit for the PE exam. This was to become effective January 1, 2015. 
However, there has been significant opposition of the implementation of $\mathrm{BOK}+30$, including a motion to rescind the rule during the 2007 NCEES annual meeting. The motion was defeated; however, the NCEES president formed a task force and charged it with devising a strategy to assist Member Boards with implementing the $\mathrm{BOK}+30$ requirements. The task force was also charged with addressing potential barriers to mobility that could result from implementing the requirement and with developing workable definitions for approved coursework and approved course providers.

At the recent 2008 NCEES annual meeting a motion was passed to delay implementation of $\mathrm{BOK}+30$ until 2020. NCEES also will begin to refer to this initiative as "Master's or equivalent" because of the various name changes the proposal has undergone. NCEES also passed a resolution that calls for NCEES leadership to assign a task force to provide the Council with a written analysis of 1) The potential educational, professional, regulatory, and economic impact of the Master's or equivalent; and 2) Any alternative solutions besides the Master's or equivalent that could potentially address the challenge of better preparing engineering licensure candidates to enter the profession. Full text of the resolution is available at the NCEES web page ${ }^{1}$.

Please note that promulgation of NCEES recommendations is a very slow process. Several years ago ( 20 years), NCEES recommended to state licensing boards that only graduates from ABETEAC program be allowed to sit for the PE. To date, 19 states have adopted that recommendation.

The proposal of $\mathrm{BOK}+30$ has resulted in at least one ABET-TAC institution to explore the idea of changing to an ABET-EAC program. Professor Jim Lambrechts from Wentworth Institute of Technology (WIT) presented a thoughtful analysis ${ }^{2}$ of the potential impacts of BOK +30 to CET programs and the civil engineering industry at the 2008 ASEE conference in Pittsburgh, PA His paper included discussion on WIT's process of remolding its CET program to CE.

\section{Conclusions}

This report required a significant amount of research that included review of internet resources, e-mail correspondence, and several telephone conversations with individuals across the country. The information gathering process has been fascinating. A common theme that arose was that the differences between CE and CET programs with curricula like ours are not significant. However, individual and institutionalized prejudices exist against CET graduates.

Both types of programs respond to primary constituents such as students, parents, employers, and graduate schools. Proposed changes to the civil engineering profession can affect both the constituents mentioned above and existing undergraduate academic programs. No one knows exactly what changes will occur to the civil engineering profession. ASCE has been proposing more and more education for years, but their proposals have met serious opposition from state licensing boards and practicing civil engineers. It is likely there will be change, but what and when are unknown.

\section{Recommendations}

The CET program at our University is currently very strong and opportunities for its graduates in gaining licensure and admittance to graduate school in increasing. We are in a position to enjoy the current environment, but we are also nimble enough to change when the facts indicate a clear advantage to action. 
It is strongly recommended that IF a CE program is created, it be administered within our department in our College, not in the separate Engineering College. However, it is not certain that the administrative politics in academia would allow an engineering program be developed outside the Engineering College. In addition, there is significant hesitancy for our College to financially support the development of an engineering program if the Engineering College could absorb the program in the future if CE became successful. The Provost at our university could not give the Dean of our college any assurance that the CE program could be "protected". If a CE program was developed and administered in the Engineering College, the collective negatives to the existing CET program and its graduates would outweigh the primary advantage of a fewer number of CE graduates' ability to become licensed in 50 states.

\section{References}

1. "Southern Zone Substitute Resolution." National Council of Examiners for Engineering and Surveying. 10 September 2008.

$><$ http://www.ncees.org/homepage/sz_resolution_as_amended.pdf

2. Lambrechts, J. "When Civil Engineering Technology is Elevated to Civil Engineering, What Can Fill the Technology Void?” ASEE Annual Conference, June 2008

3. "Curriculum Guide \& Curriculum Options for Undergraduates". The Ohio Sate University, Civil \& Environmental Engineering \& geodetic Science. 18 July 2008.

$<$ http://www.ceegs.ohio-state.edu/CEUNDERGRAD/doc/Handbook\%2007.pdf $>$

4. "Course Descriptions - Civil Engineering." Rose-Hulman Institute of Technology. 18 July 2008. <http://www.rose-hulman.edu/Catalog0708/courses-civil.htm>

5. "Civil Engineering Program Description." Stanford Civil \& Environmental Engineering. 18 July 2008. $<\underline{\text { http://cee.stanford.edu/documents/Civil-Engr-major.pdf }>}$

6. “Curriculum.” Civil and Environmental Engineering, University of Cincinnati. 18 July 2008. $<$ http://www.uc.edu/degreeprograms/Program.aspx?program=20BSCE-CE $>$

7. "Recommended Plan of Study, BS Civil Engineering." Drexel University. 18 July 2008. $<$ http://coreapp1.drexel.edu/webplanofstudy/plan.asp?plan id=30>

8. "Curriculum map - pdf download." Oregon Institute of Technology, Civil Engineering. 18 July 2008. http://www.oit.edu/programs/civil

9. “Civil Engineering Technology, Florida A\&M." Florida A\&M University, College of Engineering Sciences, Technology \& Agriculture. 7 July 2008. < http://www.famu.edu/index.cfm?a=cesta $>$

10. "Civil Engineering." Florida A\&M University - Florida State University (FAMU-FSU), College of Engineering. 7 July 2008. < www.eng.fsu.edu/>

11. “Civil Engineering Technology." Old Dominion University, Frank Batten, College of Engineering \& Technology, Department of Engineering Technology. 7 July 2008. < www.eng.odu.edu/et/academics/cet/cet.shtml>

12. "Civil Engineering." Old Dominion University, Frank Batten, College of Engineering \& Technology, Department of Civil and Environmental Engineering. 7 July 2008. $<$ www.eng.odu.edu/cee/ $>$ 
13. "Civil Engineering Technology w/Environmental Option." University of Massachusetts Lowell, James B. Francis College of Engineering. 7 July 2008. < http://continuinged.uml.edu/engtech/civil_eng.htm>

14. "Civil Engineering." University of Massachusetts Lowell, James B. Francis College of Engineering. 7 July 2008. < http://www.uml.edu/college/engineering/Civil/Default.html >

15. "Civil Engineering Technology.” University of North Carolina Charlotte, William States Lee College of Engineering. 7 July 2008. < $\underline{\text { http://www.et.uncc.edu/civil/index.html }>}$

16. "Civil Engineering." University of North Carolina Charlotte, William States Lee College of Engineering. 7 July 2008. <http://www.ce.uncc.edu/index.htm>

17. "Construction Engineering Technology." University of Toledo, College of Engineering, Department of Engineering Technology. 7 July 2008. $<$ http://www.cet.et.utoledo.edu/CET home.html $>$

18. “Civil Engineering." University of Toledo, College of Engineering, Department of Civil Engineering. 7 July 2008. <http://www.eng.utoledo.edu/civil/>

19. "Civil \& Construction Engineering Technology." Youngstown State University, College of Science, Technology, Engineering, and Mathematics, School of Technology. 7 July 2008. $<\underline{\text { http://www.eng.ysu.edu/programs/tech/Programs/CET.htm }>}$

20. "Civil Engineering." Youngstown State University, College of Science, Technology, Engineering, and Mathematics, School of Technology. 7 July 2008. $<$ http://www.eng.ysu.edu/programs/ceegr/>

21. "Criteria for Accrediting Engineering Programs 2008-2009 Accreditation Cycle." ABET.ORG. 1 July 2008. < http://www.abet.org/Linked\%20DocumentsUPDATE/Criteria $\% 20$ and $\% 20 \mathrm{PP} / \mathrm{E} 001 \% 2008-09 \% 20 \mathrm{EAC} \% 20 \mathrm{Criteria} \% 2012-04-07$. pdf $>$

22. Hart, Frank. Telephone interview. 19 August 2008.

23. Stratton, John. "Re: civil engineering in CAST?” E-mail to author. 9 July 2008.

24. Baker, David. Telephone interview. 16 July 2008.

25. Dettman, Matthew. Telephone interview. 9 September 2008.

26. Basanta, Robert. Telephone interviews. September 2008.

27. "NCEES Licensing Boards Survey.” NCEES.ORG. July 2008. https://commerce.ncees.org/surveyor/results/index.php?survey_id=1003\&section_id=9\&ques $\underline{\text { tion } \mathrm{id}=84}$

28. "Licensing Board Rules and Regulations." July 2008. http://www.ncees.org/licensure/licensing_boards/

29. State Licensing Boards. Telephone interviews. August 2008

30. Various. "Re: ABET-TAC Licensure." Responses to author's e-mail. 4 September 2008.

31. Wolcott, Scott. "civil engineering technology vs. civil engineering." Questionnaire to CET co-op employers. August/September 2008.

32. DiGennaro, Nicholas. Personal Interview. May 2008. 